\title{
Mantle xenoliths and xenocrysts from the Cross kimberlite, British Columbia, Canada: implications for upper mantle evolution beneath western Canada
}

\author{
Douglas C. Hall \\ Microscopy and Microanalysis Facility \\ University of New Brunswick \\ Fredericton, NB, Canada, E3B 5A3
}

The Cross kimberlite is located in the Front Ranges of the Rocky Mountain Fold and Thrust Belt of southeastern British Columbia, Canada. This Early Triassic intrusion postdates Proterozoic to Early Paleozoic extensional magmatism, and predates the Mesozoic-Cenozoic thrusting of the Columbian Orogeny. It has therefore been transported $>100 \mathrm{~km}$ northeastward relative to the mantle and crystalline basement through which it penetrated. The kimberlite intruded Pennsylvanian sedimentary rocks of the Bourgeau thrust sheet, which contains a facies change that marks the western edge of deposition on thick continental crust (Price 1981). The highly altered suite of xenoliths and xenocrysts is derived from the mantle beneath the extensional western margin of Paleozoic North America.

Mantle xenoliths are extensively serpentinized. Garnet, spinel, and amphibole are the only primary phases commonly preserved. Spinel peridotite predominates over garnet peridotite. Eclogites and megacrysts are absent. The xenoliths are friable, and few were recovered, but xenocrysts are common in the kimberlite. Spinel and garnet predominate, although amphibole and clinopyroxene xenocrysts have been recovered. Unaltered olivine and orthopyroxene xenocrysts have not been found.

Olivine is $\mathrm{Fo}_{92}$ in garnet peridotite and $\mathrm{Fo}_{90}$ in spinel peridotite. Orthopyroxene and clinopyroxene exhibit a bimodal distribution of $\mathrm{Al}_{2} \mathrm{O}_{3}$ contents reflecting derivation from garnet $\left(\mathrm{Al}_{2} \mathrm{O}_{3}<2 \mathrm{wt} \%\right)$ or spinel $\left(\mathrm{Al}_{2} \mathrm{O}_{3}>3 \mathrm{wt} \%\right)$ peridotite. Clinopyroxene xenocrysts (this study and Fipke et al 1989) exhibit a similar distribution of $\mathrm{Al}_{2} \mathrm{O}_{3}$ contents.

Garnet in xenoliths is Mg-rich $(\mathrm{Mg} /(\mathrm{Mg}+\mathrm{Fe})>0.82)$ and $\mathrm{Cr}$-rich $\left(\mathrm{Cr}_{2} \mathrm{O}_{3}=5-10.5 \mathrm{wt} \%\right)$. The compositional range of xenocrysts is more extensive and defines four groups (Fig. 1). One group consists of red to purple
Mg-rich lherzolite garnet $(\mathrm{Mg} /(\mathrm{Mg}+\mathrm{Fe})>0.82)$ with a extensive range of $\mathrm{Cr}_{2} \mathrm{O}_{3}$ contents (1.5-10.0 wt.\%). All xenolith garnet compositions fall within this group. Another group of xenocrysts consists of orange Mgpoor lherzolitic garnet $(\mathrm{Mg} /(\mathrm{Mg}+\mathrm{Fe})<0.82)$ that is relatively Ti- and Cr-poor $\left(\mathrm{Cr}_{2} \mathrm{O}_{3}<4.5 \mathrm{wt} \%\right)$, and has no equivalents among the xenoliths. This group is relatively Ca-rich at a given $\mathrm{Cr}_{2} \mathrm{O}_{3}$ content compared to the Mg-rich group, and defines a steeper array on the $\mathrm{CaO}-\mathrm{Cr}_{2} \mathrm{O}_{3}$ plot. A third group of xenocrysts is Feand Ti-rich, and has compositions similar to Cr-poor megacrysts. The fourth group consists of uncommon Ca-poor G10 garnet $(\mathrm{CaO}<3 \mathrm{wt} \%)$, consistent with a harzburgite source.

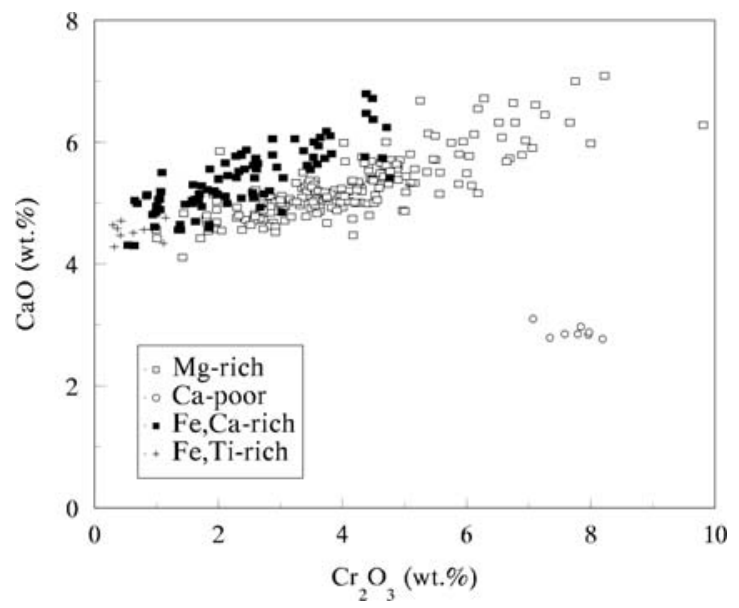

Figure 1: $\mathrm{CaO}$ versus $\mathrm{Cr}_{2} \mathrm{O}_{3}$ plot of Cross garnet xenocrysts.

Spinel compositions in garnet xenoliths have a restricted range $(\mathrm{Cr} /(\mathrm{Cr}+\mathrm{Al})=0.7-0.8)$ relative to those in garnet-free xenoliths $(\mathrm{Cr} /(\mathrm{Cr}+\mathrm{Al})=0.1-0.9)$. Xenocrysts encompass the entire range. There are no criteria to unambiguously distinguish between 
xenocrysts derived from garnet-bearing versus garnetfree peridotite, particularly in the absence of an abundant suite of xenoliths, but many of the relatively Cr-poor xenocrysts may be derived from spinel peridotite. The Al-poor xenocrysts $(\mathrm{Cr} /(\mathrm{Cr}+\mathrm{Al})>0.8)$ are relatively $\mathrm{Ti}$ - and $\mathrm{Fe}^{3+}$-rich, and may be related to metasomatism. The Al-poor spinel in one garnet-free xenolith $(\mathrm{Cr} /(\mathrm{Cr}+\mathrm{Al})=0.91)$ is texturally associated with phlogopite. Amphibole compositions range from edenitic hornblende to pargasite, typical of hornblende peridotite.The restricted mineral assemblages limit application of thermobarometric techniques. Two garnet peridotites yield $\sim 1100^{\circ} \mathrm{C}$ at $43 \mathrm{~kb}$. Single pyroxene thermobarometry (Nimis and Taylor 2000), as applied to Al-poor clinopyroxene xenocrysts yields $\sim 870^{\circ} \mathrm{C}$ at $46 \mathrm{~kb}$, and those reported by Fipke et al. (1989) give $\sim 1030^{\circ} \mathrm{C}$ at $44 \mathrm{~kb}$ and $830^{\circ} \mathrm{C}$ at $36 \mathrm{~kb}$. Nickel thermometry applied to a subset of the garnet xenocrysts gives a range of $890-1350^{\circ} \mathrm{C}$ (Canil et al. 2003). Zn contents in spinel in xenoliths (Ryan et al. 1996) give $900-1150^{\circ} \mathrm{C}$ for garnet-bearing xenoliths and $575-750^{\circ} \mathrm{C}$ for garnet-free xenoliths. Spinel xenocrysts yield $580-1170^{\circ} \mathrm{C}$, with most between 600 $820^{\circ} \mathrm{C}$. Many of the latter are likely derived from garnet-free xenoliths.

The kimberlite sampled a significant depth range, including both depleted and relatively fertile mantle. Highly depleted harzburgitic mantle, as evidenced by the low-Ca garnet xenocrysts, was not sampled in abundance, and may be a very minor component of the underlying mantle. Among the lherzolite-trend garnets xenocrysts, trace element concentrations reported by Canil et al. (2003) indicate a general lack of the highly depleted compositions that are typical of Archean mantle. The substantial population of Fe-rich garnet xenocrysts, however, implies the presence of a significant relatively fertile mantle reservoir. The Feand Ca-rich compositions plot along the CCGE trend of Kopylova et al. (2000), and may be derived from spinel-bearing peridotite. These Fe- and Ca-rich garnet xenocrysts from Cross have elevated $\mathrm{Sc} / \mathrm{V}$ ratios relative to Mg-rich xenocrysts (Fig. 2), a feature that may result from preferential partitioning of $\mathrm{V}$ into coexisting spinel.

The Rocky Mountains in southeastern British Columbia overlie the Archean Hearne Province (Ross et al. 1991), yet the Cross kimberlite apparently sampled little Archean mantle. Canil et al. (2003) attributed this to Proterozoic replacement or modification of the mantle root, possibly during the accretion of the Wyoming Province to Laurentia. The Triassic mantle sampled by the Cross kimberlite, located beneath the western edge of thick continental crust on the margin of North America, evidently still possessed a root that survived Late Proterozoic to Early Phanerozoic extension and magmatism.

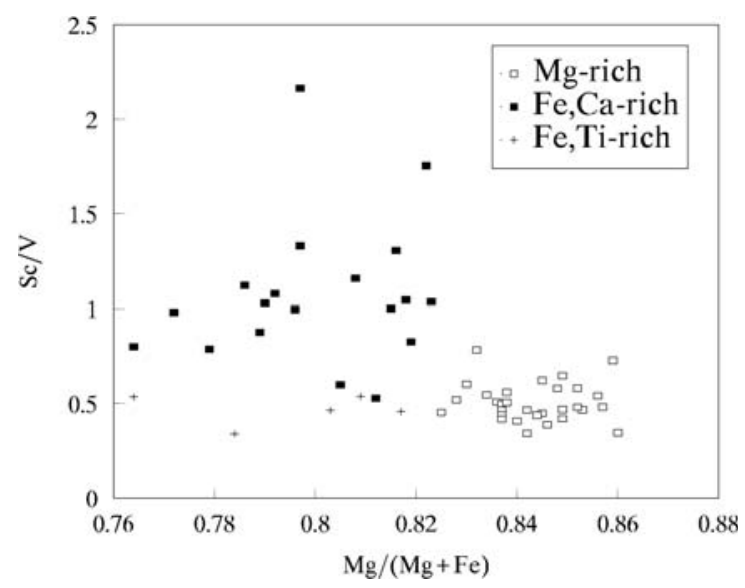

Figure 2: $\mathrm{Sc} / \mathrm{V}$ versus $\mathrm{Mg} /(\mathrm{Mg}+\mathrm{Fe})$ plot for Cross garnet xenocrysts. Sc and $\mathrm{V}$ values from Canil et al. (2003).

\section{References}

Canil, D., Schulze, D.J., Hall, D., Hearn, B.C. Jr., Milliken, S.M. 2003. Lithospheric roots beneath western Laurentia: the geochemical signature in mantle garnets. Canadian Journal of Earth Sciences 40, 1027-1051.

Fipke, C.E., Gurney, J.J., Moore, R.O., Nassichuk, W.W. 1989. The development of advanced technology to distinquish between productive diamondiferous and barren diatremes. Geological Survey of Canada Open File 2124.

Kopylova, M.G., Russell, J.K., Stanley, C., Cookenboo, H. 2000. Garnet from Cr- and Ca-saturated mantle: implications for diamond exploration. Journal of Geochemical Exploration 68, 183-199.

Nimis, P., Taylor, W.R. 2000. Single clinopyroxene thermobarometry for garnet peridotites. Part 1. Calibration and testing of a Cr-in-cpx barometer and enstatite-in-cpx thermometer. Contributions to Mineralogy and Petrology 139, 541-554.

Price, R.A. 1981. The Cordilleran foreland thrust and fold belt in the southern Canadian Rocky Mountains. In: McClay, K.R. and Price, N.J. (eds.) Thrust and Nappe Tectonics, Geological Society of London Special Publication 9, 427-448.

Ross, G.M., Parrish, R.R., Villeneuve, M.E., Bowring, S.A. 1991. Geophysics and geochronology of the crystalline basement of the Alberta Basin, western Canada. Canadian Journal of Earth Sciences 28, 512-522.

Ryan, C.G., Griffin, W.L., Pearson, N.J. 1996. Garnet geotherms: pressure-temperature data from $\mathrm{Cr}$ pyrope garnet xenocrysts in volcanic rocks. Journal of Geophysical Research 101, 5611-5626. 